\title{
Geochemistry of intercalated red and gray pelagic shales from the Mazak Formation of Cenomanian age in Czech Republic
}

\author{
1 State Key Laboratory for Mineral Deposits Research, Department of Earth Sciences, Nanjing University, Nanjing 210093, China. \\ E-mail: shyjiang@nju.edu.cn \\ 2 Center for Marine Geochemistry Research, Nanjing University, Nanjing 210093, China \\ 3 Geological Survey of Canada- Atlantic, Dartmouth, N.S. Canada, B2Y 4A2 \\ 4 Institute of Geological Engineering, VSB-Technical University Ostrava, 17. listopadu 15, CZ-70833 Ostrava-Poruba, Czech Republic. \\ E-mail: petr.skupien@vsb.cz
}

Pelagic red and gray shales are intercalated within the lower part of the Mazak Formation of Middle Cenomanian age in Czech Republic. A detailed geochemical study of major, trace and rare earth elements and carbon isotopic compositions of organic carbon has been conducted on sixteen red and gray shales. The data suggest that the shales were most likely accumulated in well-oxygenated bottom waters with very limited organic matter supply and consisted of marine organic matter mixed with minor amounts of terrestrial organic matter. The shales were deposited below CCD in one of the tectonic troughs developed along northern margin of the western Tethys. Similar geochemical covariances of major, trace and rare earth elements for the shales suggest palaeoceanographic conditions and provenance during their deposition. The most probable cause for the variation of redox bottom conditions in the mid-Cretaceous deep ocean was periodic changes in the concentration of dissolved oxygen in bottom waters, due to changes in deep water circulation and processes driven climate changes.

\section{Introduction}

Cyclicity of multicolored pelagic shales (e.g., red-brown, green gray, black) has been widely recognized in the deep-water sedimentary sequences (Lancelot et al., 1972; Jansa et al., 1979; Arthur, 1979; Dean et al., 1984; 1989; Wortmann et al., 1999). These cycles have been suggested to relate to climatic controls on influx of terrigenous organic matter and sediment, rates of upwelling, productivity, and dissolved oxygen concentration in deep waters (Dean et al., 1984). In particular, the Lower Cretaceous sediments are frequently characterized by a well-expressed cyclicity (Dean et al., 1978; Jansa et al., 1979; Wortmann et al., 1999). In the deep western Tethys basin most of the middle and late Cretaceous strata were deposited below the carbonate compensation depth (CCD), resulting in carbonate-poor and clay-rich cyclic inter-bedding of red, green, and black shale. The pelagic red clays become the dominant deep sea deposit in western Tethys during the late Cretaceous to early Eocene (Jansa et al., 1979). It is suggested that significant chemical, physical, and mineralogical variations in these pelagic shale sequence may reveal controlling factors influencing the sedimentary environment that is affected by changing chemical, tectonic, oceanographic, and climatic influences (Zhou and Kyte, 1992). However, the origin and significance of the pelagic variegated shale remain a controversy (Lancelot et al., 1972; Vogt, 1972; Dean and Arthur, 1987; Arthur, 1979). A number of studies have focused on the cyclicity of black shales in Earth history, e.g., Wortmann et al. (1999) performed a detailed major-element geochemical analysis of a $3 \mathrm{~m}$ long section of cyclically alternating black/green shales of latest Aptian age from the western Tethys. They interpreted the data as indicating periodic changes from a high-productivity and well-oxygenated green shale mode, to a lowproductivity oxygen-deficient black shale mode. The detailed study on origin and geochemistry of the cyclically alternating red/green shale is lacking.

In recent years, the study of Cretaceous red-colored pelagic sediments, named as CORB (Cretaceous Oceanic Red Beds), has attracted great attention in the international community, and fundamental changes in the oxidation state, the circulation, and the carbon budget of the ocean during the deposition of these red beds have been suggested (Melinte and Jipa, 2005; Wang et al., 2005; Hu et al., 2005a,b; Neuhuber et al., 2007).

Here, we report a detailed major, trace and rare earth element, and carbon isotope study on a section of variegated shale of Cenomanian age, from the Mazak Formation in Czech Republic. The section is comprised of cyclically alternating red and gray shales. Geochemical study is an attempt to elucidate the cause of color banding of the shales and the palaeoceanographic processes during the deposition of these cyclic multi-colored pelagic deep-sea sediments. 


\section{Geological background}

In Czech Republic, the Cretaceous strata outcrop at many places in the Carpathian Mountains chain. The most significant Cretaceous area in Czech Republic represents Silesian Unit (outer Western Carpathians) in the Moravskoslezske Beskydy Mts. The geology of the Silesian Unit (Silesian Nappe), and its lithostratigraphy was recently reviewed by Picha et al. (2006). In the Bystry potok near Trojanovice, nearby Frenstat p. R. (Figure 1), an almost continuous, favorably inclined section outcrops, containing pelitic deposits of the Lhoty Formation, comprised of highly bioturbated black shales developed in a Scisti e Fucoidi facies of Albian age. These are overlain by variegated shale strata of the Mazak Formation (Fig.2), which in turn are overlain by the lower part of the Godula Formation. The sequence stratigraphically spans Albian to Campanian. The higher part of the Godula Formation is represented by over $1 \mathrm{~km}$ thick sandstone turbidites. The Mazak Formation consists of intercalated red and greenish-light gray shales several centimeters up to 10$20 \mathrm{~cm}$ thick (Fig. 3). According to only sporadically occurring dinocysts, the Mazak Formation in the studied section belongs to the upper Middle and the Late Cenomanian.

Detailed profile of red and gray beds within the Mazak Formation of Middle-Late Cenomanian age sampled for geochemical study is

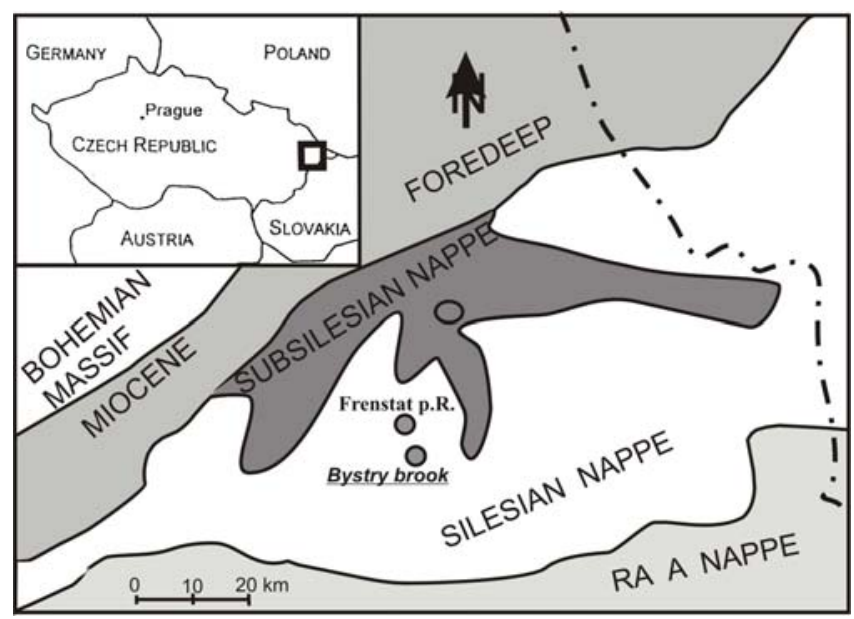

Figure 1. A geological sketch map of the studied area.

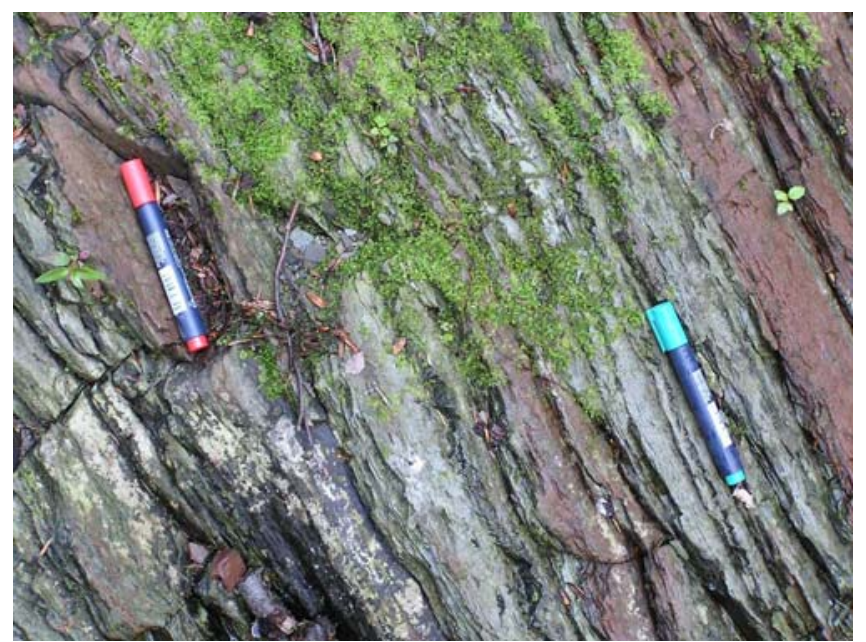

Figure 2. Red and gray shales of the Mazak Formation in Czech Republic.

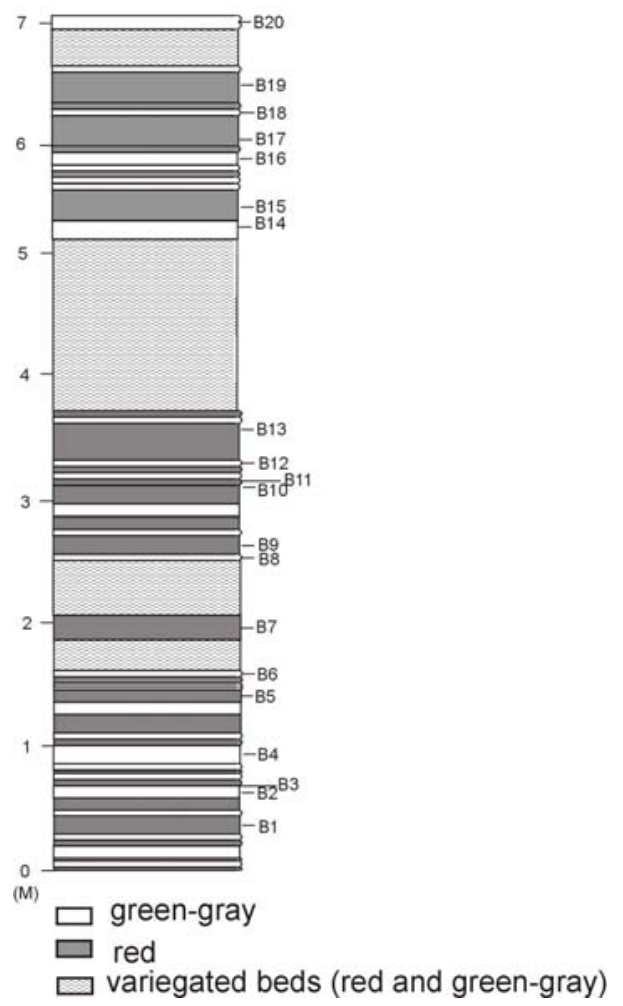

Figure 3. Stratigraphic section of the sampled Mazak Formation in Czech Republic.

shown in Fig.3. Red shales are intercalated with greenish gray shales and rare are thin beds of sandstone turbidite that become frequent higher up the section. A petrographic study of the sampled red and gray shales has shown only minor variations in the quantitative composition of mineral phases present. Main components are quartz, plagioclase, and clay minerals (Table 1). Lack of carbonates and calcareous fossils in the samples indicate their deposition below CCD.

\section{Sampling and analytical methods}

Sixteen samples of red and gray shale from the Mazak Formation were collected from a well-exposed outcrop. During sampling, the un-weathered intervals are selected and the weathered parts of the rock have been carefully avoided in the field. In laboratory, the surface layers of rock samples were first cut away, and then these samples have been grinded into small pieces and only fresh portions of rock piece were hand picked, powdered and used for further geochemical study.

Table 1. Estimated typical mineral composition of shales in the Mazak Formation (vol\%)

\begin{tabular}{|l|l|l|}
\hline & Red shale & Gray shale \\
\hline Amorphous part & $0 \pm 5.4$ & $4.7 \pm 6.6$ \\
\hline Chlorite & $7.24 \pm 2.04$ & $7.81 \pm 1.8$ \\
\hline $\begin{array}{l}\text { Illite-smectite or glauconite- } \\
\text { smectite }\end{array}$ & $40.6 \pm 4.2$ & $53.3 \pm 5.7$ \\
\hline Plagioclase (albite) & $5.78 \pm 0.87$ & $4.71 \pm 0.87$ \\
\hline Quartz & $47.07 \pm 1.92$ & $29.41 \pm 1.56$ \\
\hline Hematite & $1.24 \pm 0.57$ & $0.15 \pm 0.22$ \\
\hline
\end{tabular}


In this study, we analyzed major, trace and rare earth elements, and TOC concentrations, together with carbon isotopic compositions of TOC, of the red and gray shales from the Czech locality. Major oxide analyses of the shale were performed using X-Ray Fluorescence Spectrometry (XRF). The loss on ignition (LOI) was determined by placing $\sim 1 \mathrm{~g}$ of powdered sample into a weighed porcelain crucible and combusting in a furnace at $\sim 1000^{\circ} \mathrm{C}$ for $4 \mathrm{hrs}$. After cooling, samples were re-weighed and LOI was calculated from the difference between pre- and post-combustion weights. Samples for XRF analysis were prepared by fusing $0.06 \mathrm{~g}$ sample with $0.6 \mathrm{~g}$ silica powder and $7.26 \mathrm{~g}$ lithium borate $\left(\mathrm{Li}_{2} \mathrm{~B}_{4} \mathrm{O}_{7}: \mathrm{LiBO}_{2}=67: 33\right)$ in a platinum crucible. The fused disks were then analyzed at the Nanjing University using a 9800XP+ X-ray fluorescence spectrometer (made by ARL Corp. of Swiss). The analytical precisions for the oxides are estimated to be $<2 \%$ for $\mathrm{Si}$ and $\mathrm{Al}$, and $<5 \%$ for other elements based on duplicated analysis of several national reference rock standards. $\mathrm{The}^{2+}(\mathrm{FeO})$ and $\mathrm{Fe}^{3+}\left(\mathrm{Fe}_{2} \mathrm{O}_{3}\right)$ were separately analyzed using a titration method.

The abundance of selected trace and rare earth elements was determined by using ICP-MS method. The shale samples $(50 \mathrm{mg}$ ) were dissolved using a mixing acid of concentrated $\mathrm{HF}$ and $\mathrm{HNO}_{3}$ (2:1 in volume) in tightly screwed Teflon beakers. After dissolution, the sample solutions were added $1 \mathrm{ml}$ concentrated $\mathrm{HNO}_{3}$ and dried twice to remove the HF in the samples. The sample solutions were finally dissolved in $2 \mathrm{ml}$ concentrated $\mathrm{HNO}_{3}$, and spiked with $10 \mathrm{ppb}$ $\mathrm{Rh}$ and made up to $50 \mathrm{ml}$ in $5 \% \mathrm{HNO}_{3}$ solution. These solutions were then measured using a Finnigan HR-ICP-MS at the State Key Laboratory for Mineral Deposits Research in Nanjing University. The analytical precision of trace and rare earth elements is better than $10 \%$ based on multiple analysis of a national reference rock standard.

The powdered samples were also analyzed for TOC (total organic carbon) content and $\delta^{13} \mathrm{C}$ TOC using an EA-IRMS (isotope ratio-mass spectrometer) (Finnigan Delta Plus XP coupled with an elemental analyzer) at Nanjing University; reproducibilities were better than $\pm 0.2 \mathrm{wt} \%$ and $\pm 0.1 \%$ or for the TOC and $\delta^{13} \mathrm{C}$ TOC, respectively, based on replicate lab standard and sample analyses.

The isotopic compositions were reported in standard delta notation (parts per 1000 or $\%$ ) : $\delta^{13} \mathrm{C}$ TOC $=\left[\left(\mathrm{R}_{\text {sample }} / \mathrm{R}_{\text {std }}-1\right)\right] \times 1000$, where $R={ }^{13} \mathrm{C} /{ }^{12} \mathrm{C}$.

All the geochemical and isotopic results are listed in Table 2.

\section{Results}

\section{Major elements}

The studied shale samples are mostly composed of $\mathrm{SiO}_{2}(64.7-$ $69.9 \mathrm{wt} \%)$ and $\mathrm{Al}_{2} \mathrm{O}_{3}(13.9-17.6 \mathrm{wt} \%)$ with total $\mathrm{SiO}_{2}+\mathrm{Al}_{2} \mathrm{O}_{3}$ $>80 \mathrm{wt} \%$ (Table 2). Other major compositions include $\mathrm{Fe}_{2} \mathrm{O}_{3}(1.86-$ $4.16 \mathrm{wt} \%), \mathrm{FeO}(1.04-2.52 \mathrm{wt} \%), \mathrm{MgO}(1.86-2.08 \mathrm{wt} \%), \mathrm{K}_{2} \mathrm{O}(2.80-$ $3.49 \mathrm{wt} \%)$, and $\mathrm{Na}_{2} \mathrm{O}(0.51-0.86 \mathrm{wt} \%)$. The major chemistry of the red and gray shales shows quite similar range of variations, but a significant higher $\mathrm{Fe}_{2} \mathrm{O}_{3}$ contents are observed for the red shales (Table 2).

The red and gray shale samples show an inverse correlation of silica content with $\mathrm{Al}_{2} \mathrm{O}_{3}$ and $\mathrm{TiO}_{2}$ (Figure 4a,b), which may indicate a dilution factor by biogenic silica or quartz to the clay minerals in the shales. An inverse correlation between silica content and $\mathrm{Fe}_{2} \mathrm{O}_{3}$ is only observed for the red shales (Figure 4c), and we suggest this may reflect a dilution factor of silica to significant hematite a)

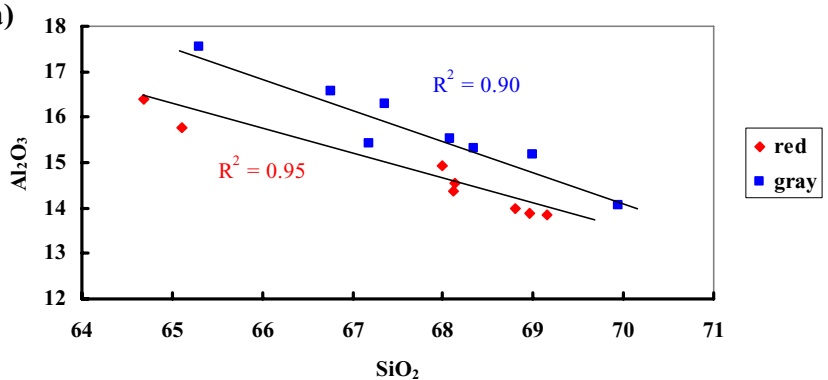

b)

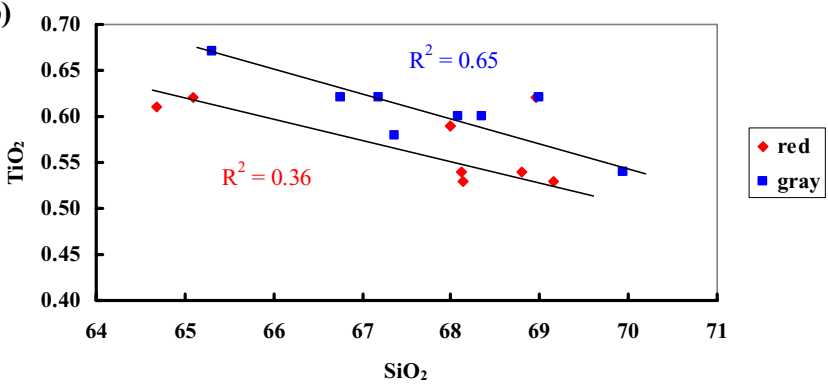

c)

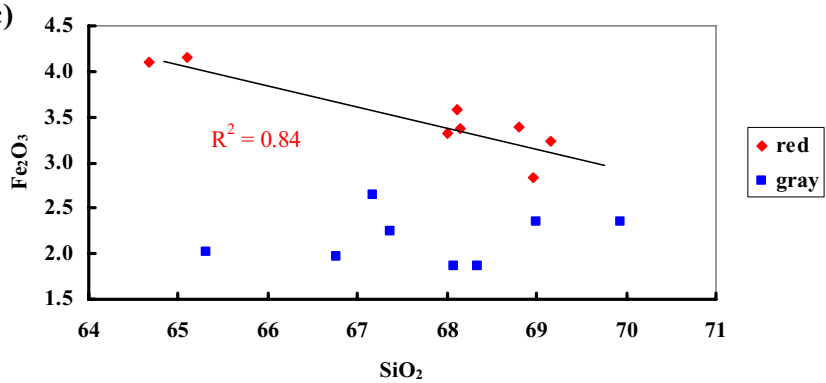

Figure 4. Plots showing correlation between (a) $\mathrm{SiO}_{2}$ and $\mathrm{Al}_{2} \mathrm{O}_{3}$, (b) $\mathrm{SiO}_{2}$ and $\mathrm{TiO}_{2}$, and (c) $\mathrm{SiO}_{2}$ and $\mathrm{Fe}_{2} \mathrm{O}_{3}$.

composition observed in the red shales, whereas hematite occurrence in the gray shales is insignificant (Table 1). A good positive linear relationship exists between $\mathrm{Al}_{2} \mathrm{O}_{3}$ and $\mathrm{K}_{2} \mathrm{O}$ or $\mathrm{Na}_{2} \mathrm{O}$ for the gray shales (Figure 5a,b), suggesting a major clay mineral component for the shales.

The major chemical compositions of the red and gray shales are comparable to PAAS (Post-Archean Australian Average Shale; Taylor and McLennan, 1985) and the average upper continental crust values (Rudnick and Gao, 2003), but a depletion by a factor of 4 to 8 in $\mathrm{CaO}$ and $\mathrm{Na}_{2} \mathrm{O}$ contents are rather significant. The $\mathrm{P}_{2} \mathrm{O}_{5}$ contents of the red and gray shales are similar $(<0.1 \mathrm{wt} \%)$ and are lower than PAAS and the upper continent crust $(0.15-0.20 \mathrm{wt} \%)$.

\section{Trace elements}

In general, the trace element concentrations of the red and gray shales are comparable with each other, and they are broadly similar to those of average upper continental crust (Rudnick and Gao, 2003). But a slight depletion in $\mathrm{Sr}, \mathrm{Zr}, \mathrm{Mo}, \mathrm{Ba}, \mathrm{Hf}$, and $\mathrm{U}$, and enrichment in $\mathrm{Li}, \mathrm{Cu}, \mathrm{Rb}$ and $\mathrm{Cs}$ is observed in both, the red and gray shales (Figure 6).

When compared to the average pelagic clays, ( $\mathrm{Li}$ and Schoonmaker, 2003), our samples show significant depletion in Mn, $\mathrm{Cu}, \mathrm{Mo}, \mathrm{Ba}$, and $\mathrm{Pb}$ (strong peaks in Figure 7). A slight depletion is also observed for Co, Ni, Sr, Y, and U (Figure 7). 
Table 2 Major, trace and rare earth element, and TOC concentrations and carbon isotope compositions of the shales.

\begin{tabular}{|c|c|c|c|c|c|c|c|c|c|c|c|c|c|c|c|c|c|c|}
\hline & $\mathrm{B} 1$ & B3 & B5 & B7 & B11 & B13 & B15 & B19 & avg. & $\mathrm{B} 2$ & B4 & B6 & B8 & B12 & B14 & B16 & B20 & avg. \\
\hline $\mathrm{SiO}_{2}(\mathrm{wt} \%)$ & 68.1 & 68.8 & 69.2 & 64.7 & 68.0 & 68.1 & 65.1 & 69.0 & 67.6 & 68.4 & 67.4 & 68.1 & 65.3 & 66.8 & 69.9 & 69.0 & 67.2 & 67.7 \\
\hline $\mathrm{Al}_{2} \mathrm{O}_{3}$ & 14.5 & 14.0 & 13.9 & 16.4 & 14.9 & 14.4 & 15.8 & 13.9 & 14.7 & 15.3 & 16.3 & 15.5 & 17.6 & 16.6 & 14.1 & 15.2 & 15.4 & 15.7 \\
\hline $\mathrm{TiO}_{2}$ & 0.53 & 0.54 & 0.53 & 0.61 & 0.59 & 0.54 & 0.62 & 0.62 & 0.6 & 0.60 & 0.58 & 0.60 & 0.67 & 0.62 & 0.54 & 0.62 & 0.62 & 0.6 \\
\hline $\mathrm{Fe}_{2} \mathrm{O}_{3}$ & 3.37 & 3.40 & 3.23 & 4.09 & 3.33 & 3.57 & 4.16 & 2.84 & 3.5 & 1.86 & 2.24 & 1.87 & 2.02 & 1.97 & 2.35 & 2.34 & 2.64 & 2.2 \\
\hline $\mathrm{FeO}$ & 2.52 & 2.37 & 2.34 & 2.12 & 2.01 & 2.30 & 2.19 & 1.94 & 2.2 & 2.12 & 1.62 & 1.86 & 1.80 & 1.76 & 1.44 & 1.40 & 1.04 & 1.6 \\
\hline $\mathrm{CaO}$ & 0.42 & 0.40 & 0.39 & 0.43 & 0.44 & 0.40 & 0.44 & 0.52 & 0.4 & 0.47 & 0.44 & 0.46 & 0.50 & 0.44 & 0.63 & 0.54 & 1.18 & 0.6 \\
\hline $\mathrm{MgO}$ & 2.08 & 2.00 & 1.98 & 2.08 & 1.96 & 2.02 & 2.08 & 1.92 & 2.0 & 2.00 & 1.97 & 1.90 & 1.98 & 1.96 & 1.86 & 1.88 & 1.94 & 1.9 \\
\hline $\mathrm{MnO}$ & 0.03 & 0.12 & 0.12 & 0.11 & 0.08 & 0.03 & 0.04 & 0.05 & 0.1 & 0.14 & 0.05 & 0.15 & 0.05 & 0.04 & 0.30 & 0.16 & 0.38 & 0.2 \\
\hline $\mathrm{K}_{2} \mathrm{O}$ & 2.98 & 2.98 & 2.92 & 3.47 & 3.32 & 3.02 & 3.28 & 3.02 & 3.1 & 3.01 & 3.21 & 3.18 & 3.44 & 3.24 & 2.80 & 3.08 & 3.25 & 3.2 \\
\hline $\mathrm{Na}_{2} \mathrm{O}$ & 0.52 & 0.58 & 0.56 & 0.61 & 0.64 & 0.54 & 0.54 & 0.55 & 0.6 & 0.80 & 0.81 & 0.75 & 0.86 & 0.80 & 0.63 & 0.67 & 0.63 & 0.7 \\
\hline $\mathrm{P}_{2} \mathrm{O}_{5}$ & 0.10 & 0.08 & 0.09 & 0.10 & 0.10 & 0.09 & 0.09 & 0.09 & 0.1 & 0.09 & 0.07 & 0.09 & 0.10 & 0.09 & 0.07 & 0.10 & 0.10 & 0.1 \\
\hline LOI & 4.34 & 4.18 & 3.16 & 4.82 & 4.25 & 4.20 & 4.71 & 4.30 & 4.2 & 4.43 & 4.60 & 4.43 & 4.81 & 4.65 & 4.42 & 4.38 & 5.26 & 4.6 \\
\hline Total & 99.57 & 99.45 & 98.35 & 99.50 & 99.66 & 99.22 & 99.04 & 98.70 & 99.2 & 99.17 & 99.25 & 98.88 & 99.11 & 98.91 & 99.05 & 99.35 & 99.64 & 99.2 \\
\hline Li (ppm) & 39 & 45 & 42 & 48 & 38 & 42 & 49 & 35 & 42 & 45 & 49 & 45 & 49 & 48 & 40 & 42 & 42 & 45 \\
\hline $\mathrm{Be}$ & 1.7 & 2.0 & 1.9 & 2.1 & 1.8 & 1.7 & 2.0 & 1.9 & 1.9 & 2.1 & 2.2 & 2.3 & 2.6 & 2.3 & 1.9 & 2.1 & 2.3 & 2.2 \\
\hline $\mathrm{Sc}$ & 7.6 & 12 & 12 & 14 & 11 & 11 & 13 & 11 & 11 & 13 & 13 & 14 & 15 & 15 & 12 & 13 & 13 & 14 \\
\hline V & 93 & 92 & 88 & 117 & 94 & 92 & 95 & 87 & 95 & 130 & 164 & 115 & 174 & 136 & 111 & 95 & 110 & 129 \\
\hline $\mathrm{Cr}$ & 72 & 65 & 63 & 74 & 62 & 59 & 72 & 61 & 66 & 68 & 71 & 74 & 80 & 75 & 63 & 72 & 72 & 72 \\
\hline Co & 23 & 24 & 24 & 22 & 20 & 22 & 21 & 20 & 22 & 21 & 21 & 21 & 22 & 21 & 20 & 18 & 20 & 21 \\
\hline $\mathrm{Ni}$ & 51 & 54 & 52 & 54 & 49 & 50 & 56 & 47 & 52 & 49 & 58 & 49 & 55 & 53 & 50 & 46 & 52 & 51 \\
\hline $\mathrm{Cu}$ & 52 & 37 & 51 & 110 & 46 & 43 & 48 & 26 & 52 & 66 & 88 & 65 & 187 & 117 & 27 & 78 & 50 & 85 \\
\hline $\mathrm{Zn}$ & 72 & 88 & 75 & 75 & 66 & 73 & 73 & 199 & 90 & 108 & 71 & 68 & 71 & 104 & 71 & 67 & 76 & 80 \\
\hline $\mathrm{Ga}$ & 15 & 16 & 16 & 18 & 15 & 16 & 18 & 16 & 16 & 17 & 20 & 18 & 19 & 18 & 17 & 18 & 19 & 18 \\
\hline $\mathrm{Rb}$ & 81 & 135 & 130 & 151 & 112 & 114 & 139 & 120 & 123 & 129 & 134 & 144 & 151 & 147 & 123 & 136 & 147 & 139 \\
\hline $\mathrm{Sr}$ & 48 & 71 & 70 & 88 & 61 & 70 & 77 & 69 & 69 & 82 & 102 & 86 & 95 & 88 & 72 & 78 & 82 & 86 \\
\hline $\mathrm{Y}$ & 12 & 16 & 17 & 19 & 15 & 18 & 16 & 15 & 16 & 19 & 23 & 19 & 21 & 21 & 17 & 18 & 15 & 19 \\
\hline $\mathrm{Zr}$ & 76 & 78 & 78 & 81 & 77 & 109 & 86 & 133 & 90 & 95 & 145 & 87 & 92 & 113 & 93 & 86 & 86 & 100 \\
\hline $\mathrm{Nb}$ & 10 & 11 & 11 & 13 & 11 & 14 & 13 & 11 & 12 & 12 & 26 & 13 & 13 & 13 & 13 & 12 & 12 & 14 \\
\hline Mo & 0.7 & 0.6 & 0.7 & 0.9 & 0.7 & 0.7 & 0.9 & 0.5 & 0.7 & 0.3 & 0.2 & 0.4 & 0.5 & 0.3 & 0.3 & 0.3 & 0.4 & 0.3 \\
\hline $\mathrm{Sn}$ & 2.8 & 2.9 & 2.9 & 3.6 & 2.9 & 2.8 & 3.4 & 2.9 & 3.0 & 3.2 & 3.8 & 3.2 & 3.4 & 3.5 & 3.0 & 3.1 & 3.0 & 3.3 \\
\hline Cs & 6.1 & 9.4 & 9.4 & 10.6 & 7.8 & 8.4 & 10.1 & 8.7 & 8.8 & 9.0 & 9.1 & 9.9 & 11 & 10 & 9.0 & 9.6 & 11 & 9.8 \\
\hline $\mathrm{Ba}$ & 240 & 353 & 343 & 392 & 327 & 371 & 343 & 391 & 345 & 387 & 365 & 398 & 399 & 392 & 347 & 356 & 393 & 380 \\
\hline $\mathrm{Hf}$ & 1.5 & 1.5 & 1.6 & 1.7 & 1.6 & 1.5 & 1.7 & 2.6 & 1.7 & 2.1 & 3.7 & 1.8 & 1.9 & 2.1 & 1.6 & 1.7 & 2.0 & 2.1 \\
\hline $\mathrm{Ta}$ & 0.7 & 0.8 & 0.7 & 0.8 & 0.8 & 0.6 & 0.8 & 0.9 & 0.8 & 1.0 & 1.3 & 0.9 & 0.9 & 1.1 & 0.8 & 0.9 & 1.1 & 1.0 \\
\hline $\mathrm{W}$ & 2.9 & 8.4 & 2.6 & 2.8 & 20 & 3.1 & 7.9 & 2.1 & 6.3 & 2.2 & 1.9 & 2.2 & 2.4 & 2.2 & 3.8 & 2.1 & 2.0 & 2.3 \\
\hline $\mathrm{Pb}$ & 24 & 22 & 25 & 27 & 19 & 21 & 25 & 17 & 22 & 17 & 16 & 15 & 340 & 33 & 14 & 18 & 37 & 24 \\
\hline $\mathrm{Bi}$ & 0.4 & 0.3 & 0.3 & 0.6 & 0.3 & 0.4 & 0.4 & 0.3 & 0.4 & 0.4 & 0.5 & 0.5 & 1.2 & 1.0 & 0.2 & 0.4 & 0.4 & 0.6 \\
\hline Th & 5.5 & 8.5 & 8.6 & 10.3 & 8.5 & 8.3 & 9.7 & 8.0 & 8.4 & 9.8 & 10.3 & 10.1 & 11 & 11 & 8.6 & 9.6 & 9.2 & 9.9 \\
\hline $\mathrm{U}$ & 1.1 & 1.2 & 1.2 & 1.4 & 1.3 & 1.2 & 1.4 & 1.3 & 1.3 & 1.6 & 1.5 & 1.6 & 3.5 & 2.0 & 1.4 & 1.9 & 1.6 & 1.9 \\
\hline $\mathrm{La}$ & 13.8 & 27.3 & 26.5 & 26.8 & 24.1 & 25.2 & 27.5 & 24.7 & 24.5 & 27.2 & 36.9 & 28.1 & 33.3 & 28.2 & 26.3 & 27.6 & 28.1 & 29.4 \\
\hline $\mathrm{Ce}$ & 58.7 & 67.5 & 64.9 & 80.0 & 58.4 & 64.1 & 68.1 & 51.5 & 64.1 & 71.0 & 104 & 77.5 & 94.4 & 80.5 & 57.2 & 68.9 & 56.7 & 76.2 \\
\hline $\mathrm{Pr}$ & 3.13 & 5.53 & 5.48 & 6.49 & 5.12 & 5.26 & 5.98 & 5.23 & 5.3 & 6.25 & 8.69 & 6.68 & 7.97 & 6.86 & 5.64 & 6.60 & 5.97 & 6.8 \\
\hline $\mathrm{Nd}$ & 11.7 & 20.2 & 19.5 & 24.2 & 18.8 & 19.3 & 21.5 & 19.3 & 19.3 & 23.8 & 32.0 & 24.7 & 30.1 & 25.6 & 20.5 & 24.0 & 21.2 & 25.2 \\
\hline $\mathrm{Sm}$ & 2.53 & 3.62 & 3.52 & 4.56 & 3.63 & 3.85 & 3.82 & 3.62 & 3.6 & 4.49 & 5.45 & 4.45 & 5.56 & 4.82 & 3.82 & 4.31 & 3.34 & 4.5 \\
\hline $\mathrm{Eu}$ & 0.56 & 0.74 & 0.76 & 0.98 & 0.78 & 0.77 & 0.80 & 0.73 & 0.8 & 0.90 & 0.96 & 0.93 & 1.09 & 0.97 & 0.76 & 0.86 & 0.68 & 0.9 \\
\hline $\mathrm{Gd}$ & 2.59 & 3.26 & 3.33 & 4.25 & 3.33 & 3.80 & 3.41 & 3.06 & 3.4 & 4.10 & 4.59 & 3.98 & 4.73 & 4.53 & 3.47 & 3.81 & 2.87 & 4.0 \\
\hline $\mathrm{Tb}$ & 0.34 & 0.41 & 0.41 & 0.53 & 0.42 & 0.51 & 0.42 & 0.40 & 0.4 & 0.52 & 0.62 & 0.50 & 0.59 & 0.55 & 0.46 & 0.48 & 0.36 & 0.5 \\
\hline Dy & 2.22 & 2.71 & 2.74 & 3.36 & 2.70 & 3.33 & 2.76 & 2.45 & 2.8 & 3.23 & 4.08 & 3.20 & 3.77 & 3.52 & 3.03 & 3.07 & 2.45 & 3.3 \\
\hline Ho & 0.46 & 0.57 & 0.58 & 0.70 & 0.55 & 0.68 & 0.57 & 0.51 & 0.6 & 0.68 & 0.83 & 0.67 & 0.75 & 0.74 & 0.62 & 0.64 & 0.53 & 0.7 \\
\hline Er & 1.34 & 1.68 & 1.74 & 2.02 & 1.64 & 1.93 & 1.68 & 1.46 & 1.7 & 1.95 & 2.44 & 1.96 & 2.23 & 2.16 & 1.85 & 1.82 & 1.63 & 2.0 \\
\hline $\mathrm{Tm}$ & 0.19 & 0.25 & 0.27 & 0.29 & 0.24 & 0.27 & 0.24 & 0.21 & 0.2 & 0.28 & 0.34 & 0.29 & 0.32 & 0.32 & 0.27 & 0.26 & 0.25 & 0.3 \\
\hline $\mathrm{Yb}$ & 1.22 & 1.66 & 1.71 & 1.89 & 1.59 & 1.70 & 1.58 & 1.36 & 1.6 & 1.94 & 2.09 & 1.90 & 2.00 & 2.09 & 1.76 & 1.72 & 1.66 & 1.9 \\
\hline $\mathrm{Lu}$ & 0.19 & 0.25 & 0.26 & 0.29 & 0.24 & 0.25 & 0.23 & 0.21 & 0.2 & 0.28 & 0.31 & 0.28 & 0.31 & 0.30 & 0.26 & 0.26 & 0.25 & 0.3 \\
\hline $\mathrm{Ce} / \mathrm{Ce}^{*}$ & 2.06 & 1.27 & 1.24 & 1.40 & 1.21 & 1.28 & 1.23 & 1.04 & 1.3 & 1.25 & 1.33 & 1.30 & 1.34 & 1.34 & 1.08 & 1.18 & 1.01 & 1.2 \\
\hline $\mathrm{Eu} / \mathrm{Eu}^{*}$ & 0.51 & 0.59 & 0.61 & 0.69 & 0.61 & 0.58 & 0.62 & 0.59 & 0.6 & 0.64 & 0.63 & 0.67 & 0.71 & 0.66 & 0.59 & 0.63 & 0.57 & 0.6 \\
\hline $\mathrm{La}_{\mathrm{N}} / \mathrm{Yb}_{\mathrm{N}}$ & 0.83 & 1.22 & 1.15 & 1.04 & 1.12 & 1.09 & 1.28 & 1.34 & 1.1 & 1.04 & 1.30 & 1.09 & 1.23 & 1.00 & 1.10 & 1.18 & 1.25 & 1.1 \\
\hline $\mathrm{Gd}_{\mathrm{N}} / \mathrm{Yb}_{\mathrm{N}}$ & 1.28 & 1.19 & 1.18 & 1.36 & 1.27 & 1.35 & 1.31 & 1.36 & 1.3 & 1.28 & 1.33 & 1.27 & 1.43 & 1.31 & 1.20 & 1.34 & 1.05 & 1.3 \\
\hline TOC (\%) & 0.04 & 0.03 & 0.03 & 0.03 & 0.03 & 0.03 & 0.04 & 0.03 & 0.03 & 0.04 & 0.04 & 0.03 & 0.03 & 0.03 & 0.04 & 0.03 & 0.04 & 0.03 \\
\hline$\delta^{13} \mathrm{C}(\% o)$ & -26.8 & -26.4 & -27.4 & -26.8 & -26.7 & -26.7 & -27.1 & -26.2 & -26.8 & -27.2 & -26.2 & -27.0 & -26.8 & -26.5 & -26.4 & -26.5 & -26.5 & -26.6 \\
\hline
\end{tabular}

Note: $\mathrm{Ce} / \mathrm{Ce}^{*}=2 \mathrm{Ce}_{\mathrm{N}} /\left(\mathrm{La}_{\mathrm{N}}+\mathrm{Pr}_{\mathrm{N}}\right) ; \mathrm{Eu} / \mathrm{Eu}^{*}=\mathrm{Eu}_{\mathrm{N}} /\left(\mathrm{Sm}_{\mathrm{N}}+\mathrm{Gd}_{\mathrm{N}}\right)^{0.5}$

In particular, the redox-sensitive elements such as $\mathrm{V}$ and $\mathrm{U}$ are generally lower but Mo concentrations are slightly higher in the red shales (Table 2). There are no significant differences in the Ni contents of the shales (Table 2). The Mn contents in red and gray shales are highly variable from 241 to $967 \mathrm{ppm}$ and 299 to $2966 \mathrm{ppm}$, respectively, with the latter having slightly higher Mn contents (Table 2). We used the Al-normalized trace element plots, and found no significant correlations between element pairs of $\mathrm{V} / \mathrm{Al}, \mathrm{Mo} / \mathrm{Al}, \mathrm{U} / \mathrm{Al}$, and $\mathrm{Th} / \mathrm{Al}$ in both the red and gray shales (Figure 8).

\section{Rare earth elements}

We normalized the rare earth elements concentration in our studied shales to the REE concentrations of Post Archaean Australian Average Shale (PAAS) compiled by Taylor and McLennan (1985).

Overall, the shale samples in our studied section show similar or slightly lower total rare earth element contents than those of PAAS, and an almost flat PAAS-normalized REE pattern (Figure 9). The red and gray shales display similar flat PAAS-normalized REE patterns with slightly heavy rare earth element (HREE) depletions 
a)

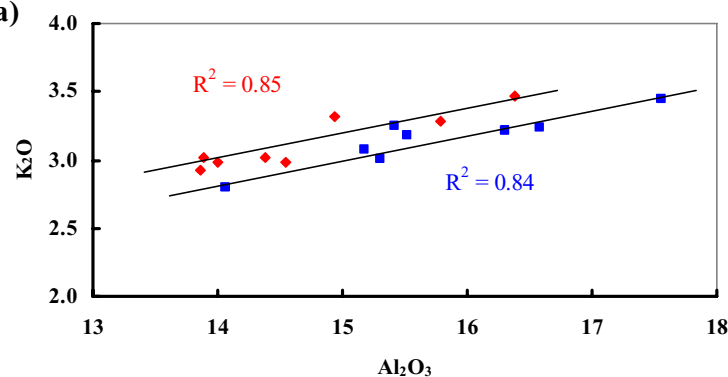

b)

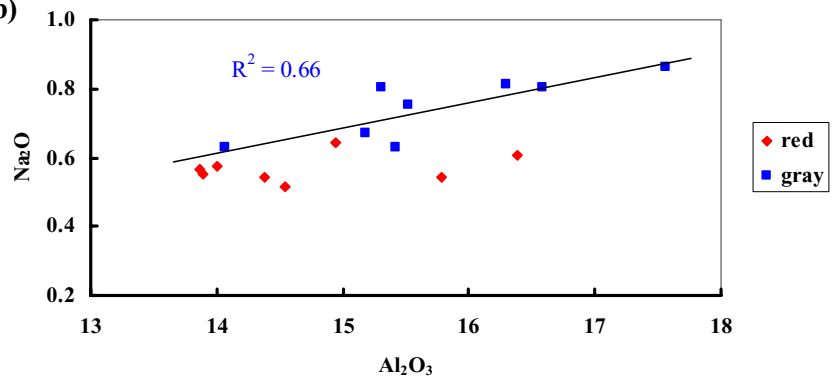

Figure 5. Plots showing correlation between (a) $\mathrm{Al}_{2} \mathrm{O}_{3}$ and $\mathrm{K}_{2} \mathrm{O}$ and (b) $\mathrm{Al}_{2} \mathrm{O}_{3}$ and $\mathrm{Na}_{2} \mathrm{O}$.

$\left(\mathrm{La}_{\mathrm{N}} / \mathrm{Yb}_{\mathrm{N}}=0.83-1.34\right.$ and $1.0-1.30$, and $\mathrm{Gd}_{\mathrm{N}} / \mathrm{Yb}_{\mathrm{N}}$ ratios $=1.18-$ 1.36 and $1.05-1.43$, respectively). Most of the red and gray shales also show significant positive $\mathrm{Ce}$ anomalies with $\mathrm{Ce} / \mathrm{Ce}^{*}$ values vary from 1.04 to 2.06 in the red shales, and 1.01-1.34 in the gray shales (Table 2). A negative Eu anomaly is observed for all the shale samples with $\mathrm{Eu} / \mathrm{Eu}^{*}$ values of $0.51-0.69$ and $0.57-0.71$ for the red and gray shales, respectively (Table 2).

\section{Organic carbon contents and carbon isotopic compositions}

The red and gray shales show no difference in their total organic carbon (TOC) concentrations and $\delta^{13} \mathrm{C}$ TOC values, which are
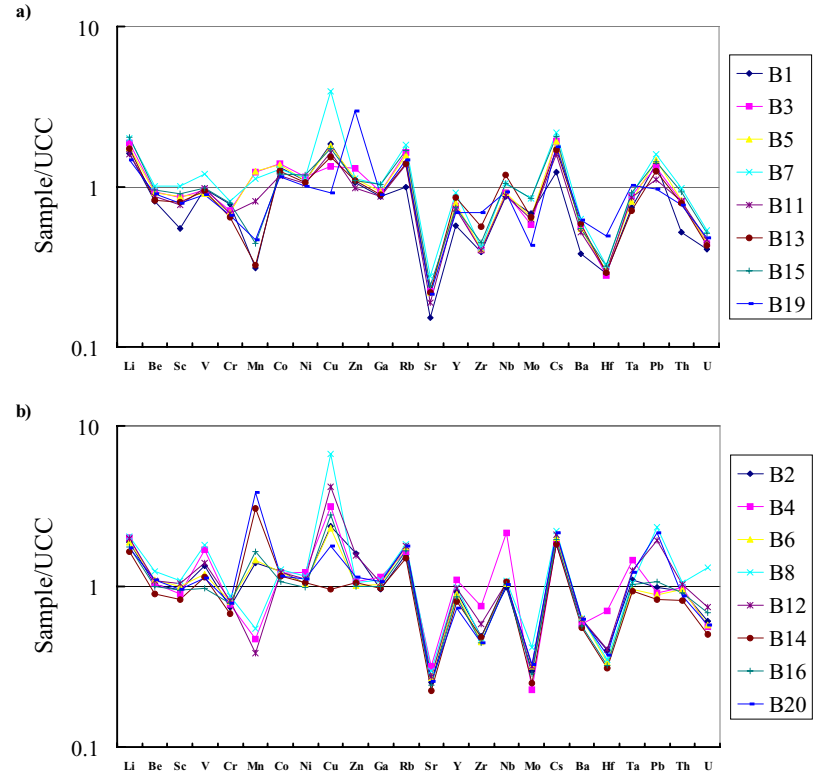

Figure 6. Trace element concentrations normalized to the average upper continental crust values (Rudnick and Gao, 2003). (a) red shales, (b) gray shales.
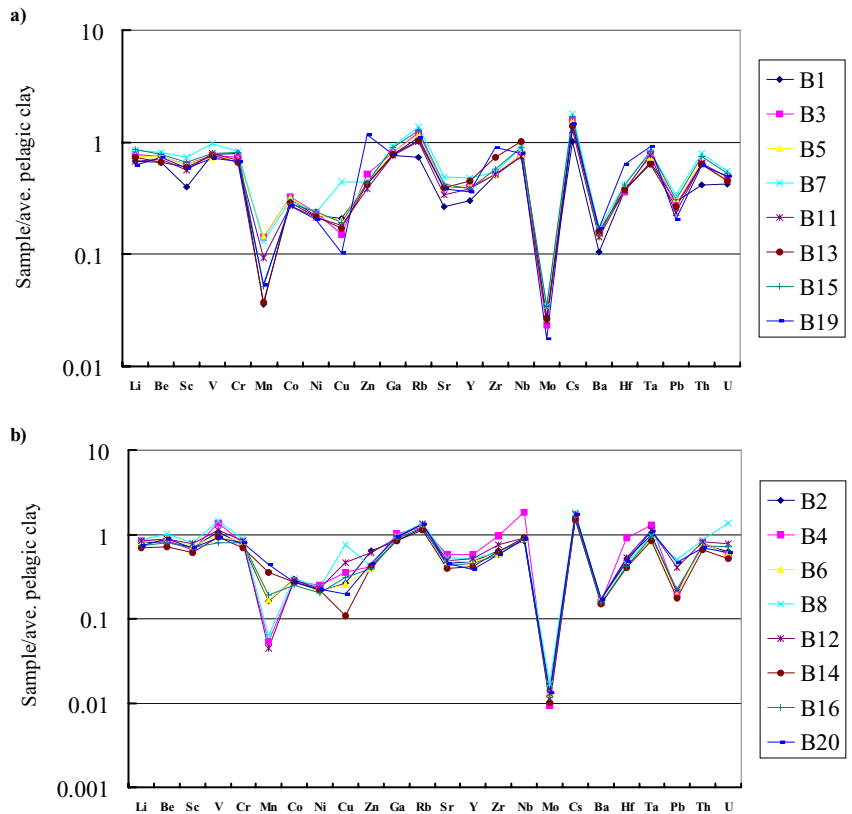

Figure 7. Trace element concentrations normalized to the average pelagic clays (Li and Schoonmaker, 2003). (a) red shales, (b) gray shales.

characterized by extremely low TOC contents of $<0.04 \mathrm{wt} \%$ with very limited $\delta^{13} \mathrm{C}$ TOC variation from -26.2 to $-27.4 \%$. In comparison, the Upper Cretaceous interbeded red and green claystones from the DSDP Leg 93 site 603 show higher TOC contents of 0.07 to $0.18 \mathrm{wt} \%$, and 0.08 to $1.14 \mathrm{wt} \%$, respectively, and the green claystones also show heavier $\delta^{13} \mathrm{C}$ TOC values of -24.3 to $-26.1 \%$ (Dean and Arthur, 1987). The TOC concentrations at the top of underlying black shales of the Lhoty Formation vary from $0.3 \%$ up to $3.5 \%$.

\section{Discussion}

\section{Origins of color banding and their implication}

The cycles of multicolored pelagic sediments in deep sea setting is a widespread phenomenon in Earth history. However, the cause for color banding and its implication for palaeoceanographic environment is still a matter of debate. Many researchers suggest that the color is caused by some compound of iron, in particular the relative abundance of the iron ion valence in the silicate structure, the specific bonding of these ions, and hematite is regarded as a pigmenting agent of red shale (Robb, 1949; Velde, 2003; Yamaguchi and Ohmoto, 2006). The source of iron has been suggested to be derived either from submarine hydrothermal venting, or from diagenetic mobilization of iron in pore water. For example, in order to explain the mineralogy and chemistry of the multicolored claystones from DSDP Leg 11 in the western North Atlantic, Lancelot et al. (1972) proposed that volcanic or hydrothermal exhalations superimposed on slow rates of pelagic clay deposition could account for the color banding, mineralogical variations and enrichments of several trace transition elements, such as $\mathrm{Mn}, \mathrm{Zn}, \mathrm{Cu}, \mathrm{Pb}, \mathrm{Cr}$, Ni. Vogt (1972) also proposed that the metal content in the Upper Cretaceous claystones was related to increased plume activity in the Atlantic at the time of their deposition. In contrast, the inter-bedding of variegated shale in the Upper Cretaceous of the western Atlantic has been suggested by Arthur (1979) to reflect diagenetic mobilization of redox-sensitive metals 


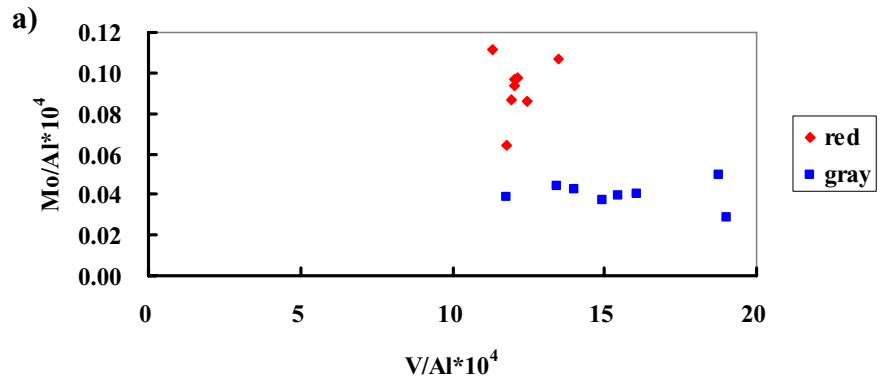

c)

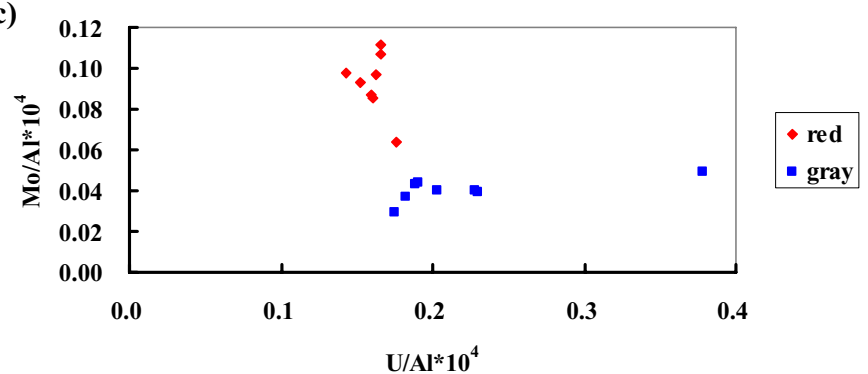

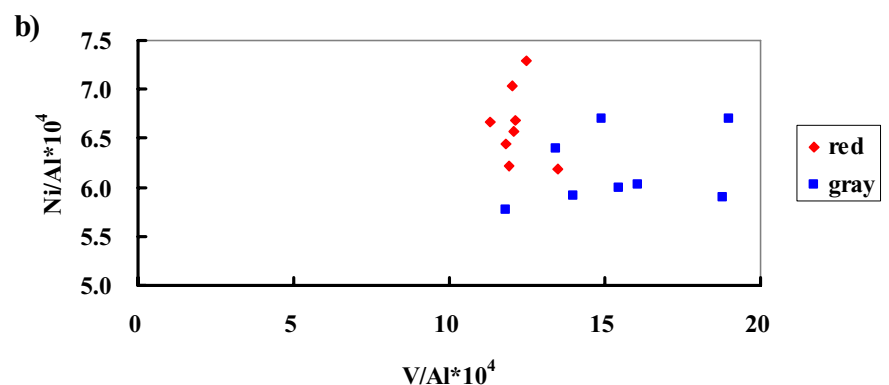

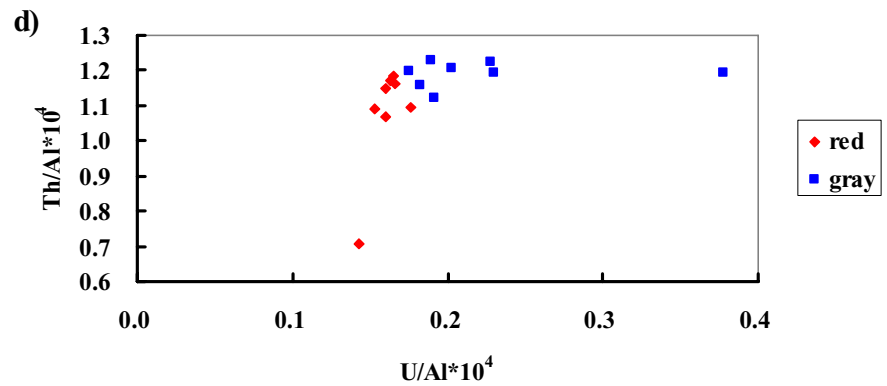

Figure 8. Interelement relationship for the Al-normalized redox-sensitive trace elements in the shales. (a) V/Al-Mo/Al, (b) V/Al-Ni/Al, (c) U/Al-Mo/Al, (d) U/Al-Th/Al.

within anoxic pore waters of the Lower Cretaceous black shales and upward diffusion/advection into the oxidized claystones. Dean and Arthur (1987) suggested a similar mechanism involving upward advection and diffusion of metals from the underlying Middle Cretaceous black carbonaceous claystones for the multicolored claystones of the overlying Upper Cretaceous to lower Tertiary sedimentary sequence at site 603 of DSDP Leg 93.

Through a study of color variability and Mn contents in the multicolored sediments from the Lomonosov Ridge in the central Arctic Ocean, Jakobsson et al. (2000) found that the high $\mathrm{MnO}$
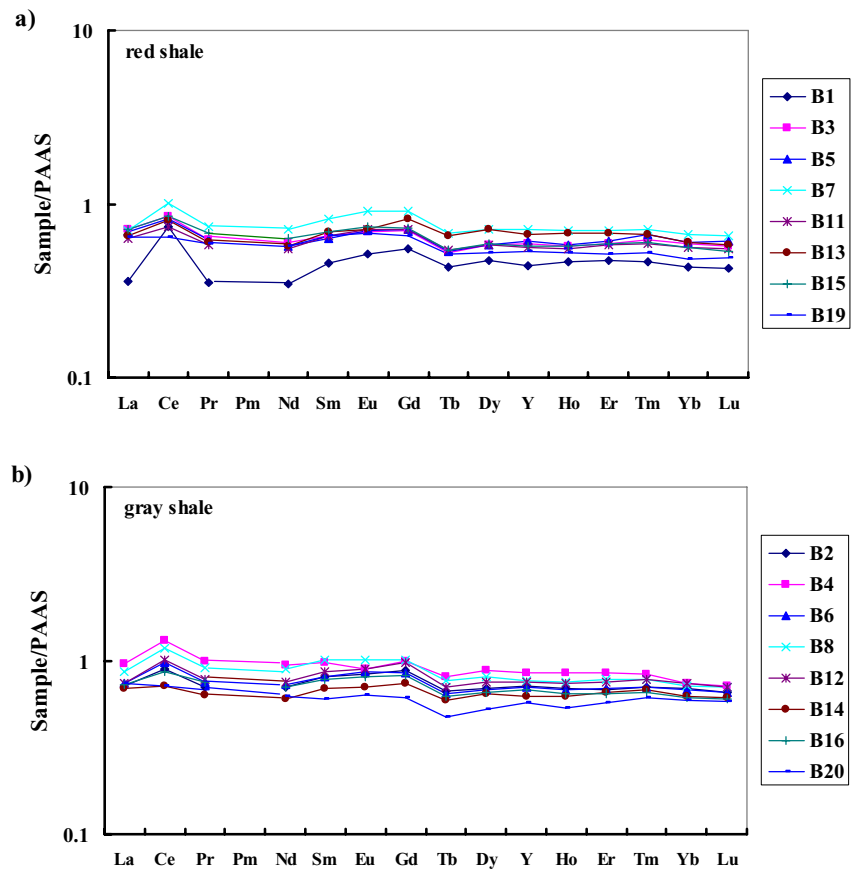

Figure 9. The PAAS-normalized REE patterns for the shales. (a) red shales, (b) gray shales. contents are corresponding to the dark to medium brown color banding in the sediment.

These authors also suggested two different processes for the cyclic pattern of color banding and manganese concentration. One is climatic forcing of the transport of source material with large quantities of manganese from northern Siberia during interglacial. The other is relative degree of ventilation of Arctic Ocean waters driven by glacialinterglacial contrasts, which would enhance the precipitation of manganese during interglacials, because of higher bottom water oxygen concentrations. Chemical analysis of the red and gray shales from the Mazak Formation revealed a difference in both the iron and manganese contents. The red shales show higher $\mathrm{Fe}_{2} \mathrm{O}_{3}$ content (2.84-4.16 wt\%) than those of the gray shales (1.86-2.64 wt\%). Mineralogically, higher hematite contents are also identified in the red shales (Table 1). However, the Mn concentration shows opposite trend with higher $\mathrm{Mn}$ in the gray shales (299-2,362 ppm) than in the red shales (241-967 ppm). Hence, we suggest that the main cause for the color banding in the pelagic sediments of the Mazak Formation is the difference in their ferric iron and hematite concentrations.

Through a study of Precambrian red beds, Yamaguchi and Ohmoto (2006) suggested that red shales are products of oxidizing environments with an adequate supply of $\mathrm{Fe}^{3+}$ that is ultimately converted to hematite, the pigmenting agent of red shales, which probably formed in situ by oxygenated pore waters during weathering of the source rocks and/or diagenesis of shales. However, if hematiterich sediments accumulated in sulfate-poor, but anoxic environments, $\mathrm{Fe}^{3+}$-oxides would leach out and gray/green shales would form.

\section{Sedimentary environments for the multicolored shales}

Using geochemical proxies, it is possible to trace the redox environments of marine sediments in Earth history (Moffett, 1990, 
Table 3. Four groups of redox conditions for low calcic shales (after QuinbyHunt and Wilde, 1996)

\begin{tabular}{|c|c|c|c|c|c|}
\hline \multicolumn{2}{|c|}{ Group } & I & II & III & IV \\
\hline & & \multicolumn{3}{|c|}{ oxic } & anoxic \\
\hline $\mathrm{Fe}$ & $(3.75 \mathrm{wt} \%)$ & $\mathrm{H}$ & $\mathrm{H}$ & $\mathrm{L}$ & $\mathrm{L}$ \\
\hline $\mathrm{Mn}$ & $(800$ ppm) & $\mathrm{H}$ & $\mathrm{L}$ & $\mathrm{L}$ & $\mathrm{L}$ \\
\hline $\mathrm{V}$ & (320 ppm) & $\mathrm{L}$ & $\mathrm{L}$ & $\mathrm{L}$ & $\mathrm{H}$ \\
\hline
\end{tabular}

Note: H - higher; L - lower

1994; Quinby-Hunt and Wilde, 1994, 1996; Yang et al., 2004; Yamaguchi and Ohmoto, 2006). For example, Th/U ratio has been used to infer paleoredox conditions in depositional environments because uranium and thorium behave differently in aqueous environments of different redox conditions. Under oxic conditions, $\mathrm{U}^{4+}$ oxidizes to highly soluble $\mathrm{U}^{6+}$, whereas $\mathrm{Th}^{4+}$ is not particularly soluble in aqueous solutions and occurs only as $\mathrm{Th}^{4+}$ in nature, which led to the geochemical decoupling of $\mathrm{U}$ and $\mathrm{Th}$ in oxidizing environments. In this study, the red shales show a $\mathrm{Th} / \mathrm{U}$ ratio of 4.96 to 7.18 , while a slight lower $\mathrm{Th} / \mathrm{U}$ ratio is observed for the gray shales (3.16-6.84). In comparison, the average Th/U ratio of PAAS and the upper continental crust is 3.8 and 3.7, respectively (Taylor and McLennan, 1985). It is suggested that the preferential loss of $U$ over Th probably occurred during diagenesis of the shale. The occurrence of red shales indicated a more oxidized environment that have slightly enhanced $U$ when compared to the gray shales.

Based on Fe, Mn, and V concentrations, Quinby-Hunt and Wilde (1996) proposed four discrete categories of depositional and early diagenetic redox conditions for low calcic shales of $[\mathrm{Ca}]<0.4 \%$ (Table 3). Group I shales are characterized by oxic conditions and high Eh with high $\mathrm{Mn}(>800 \mathrm{ppm}$, average 1,300 ppm) and $\mathrm{Fe}$ (>37,500 ppm, average $56000 \mathrm{ppm}$ ) but low V ( $<320 \mathrm{ppm}$, average $130 \mathrm{ppm}$ ) concentrations. Fe and $\mathrm{Mn}$ are present as insoluble $\mathrm{Mn}$ and Fe oxides in this group. Group II shales are deposited under anoxic, nitrate reducing to sulfate reducing conditions at intermediate $\mathrm{pH}$. Mn concentrations are low $(<750 \mathrm{ppm}$, average $310 \mathrm{ppm})$ owing to its reduction to soluble $\mathrm{Mn}^{2+}$, while $\mathrm{Fe}$ may remain bound in oxides or sulfides with concentrations comparable to Group I. Concentration of $\mathrm{V}$ in this group is also low $(<320 \mathrm{ppm}$, average $140 \mathrm{ppm})$.

Group III shales are characterized by anoxic but non-sulfate reducing Eh conditions and intermediate to low $\mathrm{pH}$, which have relatively low Fe (<37,500 ppm, average 23,000 ppm), Mn (<750 ppm, average $170 \mathrm{ppm})$, and $\mathrm{V}(<320 \mathrm{ppm}$, average $170 \mathrm{ppm})$ concentrations. Group IV shales are characterized by relatively low Fe $(<37,500 \mathrm{ppm}$, average 19,000 ppm) and $\mathrm{Mn}(<750 \mathrm{ppm}$, average $76 \mathrm{ppm}$ ) but high $\mathrm{V}$ (>320 ppm, average $1500 \mathrm{ppm}$ ) concentrations, indicating deposition under conditions of high organic matter preservation, suggesting low $\mathrm{pH}$ and Eh conditions and possibly conditions favoring methanogenesis (Quinby-Hunt and Wilde, 1994, 1996). On average, the Fe, Mn, V concentrations in the red and gray shales in our studied section suggest they belong to Group I of oxic conditions.

The Ce anomaly in ancient marine sediments is one of the promising tools to trace oceanic redox conditions. A negative $\mathrm{Ce}$ anomaly is commonly observed in modern seawater because $\mathrm{Ce}^{3+}$ in seawater can be oxidized to insoluble $\mathrm{Ce}^{4+}$ and then removed (e.g., Piper, 1974; Elderfild, 1988; Piepgras and Jacobsen, 1992). Moffett $(1990,1994)$ suggested that this Ce oxidation took place relatively rapidly in the shallow water environment through bacterial mediation.

Under oxidized conditions, compared to the other REE, Ce is hard to dissolve into water due to insoluble $\mathrm{Ce}^{4+}$. The resulting solution attains a negative $\mathrm{Ce}$ anomaly and the residue has a positive $\mathrm{Ce}$ anomaly. The hydrogenetic Fe-Mn nodules and crusts usually show a positive $\mathrm{Ce}$ anomaly due to oxidative scavenging of $\mathrm{Ce}$ by Fe-Mn oxyhydroxides (Pattan and Banakar, 1993; Bau et al., 1996). It is suggested that the REE in Fe-Mn nodules and crusts are derived from oxic seawater that typically shows a pronounced negative Ce anomaly (Elderfield, 1988). In the studied red and gray shales, we suggest that the positive Ce anomaly may indicate an oxic condition during sediment deposition and/or diagenesis. In a plot of $\mathrm{Eu} / \mathrm{Eu}^{*}$ and $\mathrm{Ce} / \mathrm{Ce}^{*}$ for shales (Figure 10), the gray shales form a linear trend; some of the red shales also plot near this trend, but several samples fall out from this trend with higher $\mathrm{Ce} / \mathrm{Ce}$ * values, which provide further evidence for a more oxidized condition for the red shales.

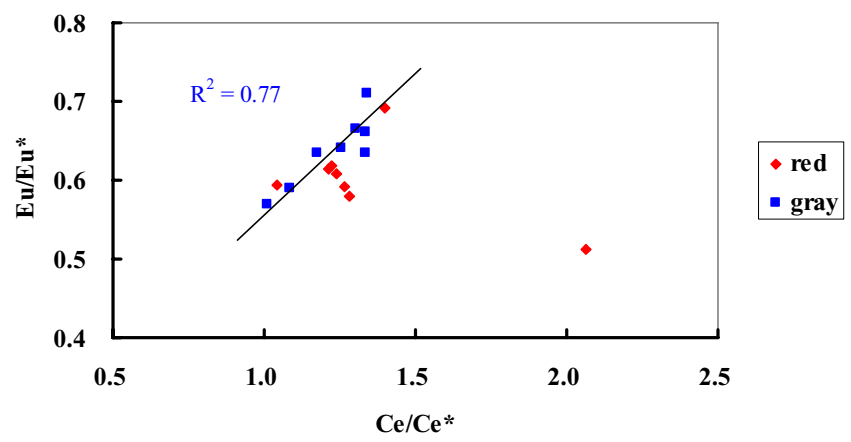

Figure 10. Correlation between $\mathrm{Eu} / \mathrm{Eu} *$ and $\mathrm{Ce} / \mathrm{ce} \mathrm{F}^{*}$ in the shales.

In pelagic sediment, barite is the only sulfate mineral present in abundance, and $\mathrm{Ba}$ enrichment has been observed from various settings, such as the Central Indian Basin, the Peru margin upwelling, and the Pacific equatorial divergence. This enrichment generally reflects high biological productivity (Von Breymann et al., 1990, 1992). Although absolute Ba concentration in our studied pelagic shales cannot be used to quantitatively estimate palaeoproductivity, the very low Ba contents (240-399 ppm) in the samples likely imply a low bioproductivity at surface water. Due to the low productivity, the trace elements in the shales are therefore also low, which is in contrast to the high concentrations of trace elements in sediments located in high bioproductivity areas (Brumsack, 1986). The low P contents in our studied shales (below average upper crust value of $742 \mathrm{ppm}$, Taylor and McLennan, 1985) further points to low nutrient availability during the periods of shale accumulation.

The similar, but extremely low TOC contents $(<0.05 \mathrm{wt} \%)$ and small variations in $\delta^{13} \mathrm{C}$ values of the red and gray shale samples in the studied section (Figure 11) indicate that the sediments were most likely accumulated in an oxygenated water body that probably contained very little organic matter. The carbon isotope compositions of organic carbon (OC) in marine sediments often have been interpreted in terms of the source of the organic matter. Previous studies have shown that Cretaceous marine $\mathrm{OC}$ had $\delta^{13} \mathrm{C}$ values of about -27 to $-29 \%$, whereas Cretaceous terrestrial OC had $\delta^{13} \mathrm{C}$ values of about -23 to $-25 \%$ o (Dean and Arthur, 1987). The carbon isotope study of OC in black claystones from DSDP Hole 603 in the western Atlantic shows a $\delta^{13} \mathrm{C}$ range from -24.4 to $-26.7 \%$, whereas the $\delta^{13} \mathrm{C}$ values of OC in DSDP Hole 367 in the eastern North Atlantic 


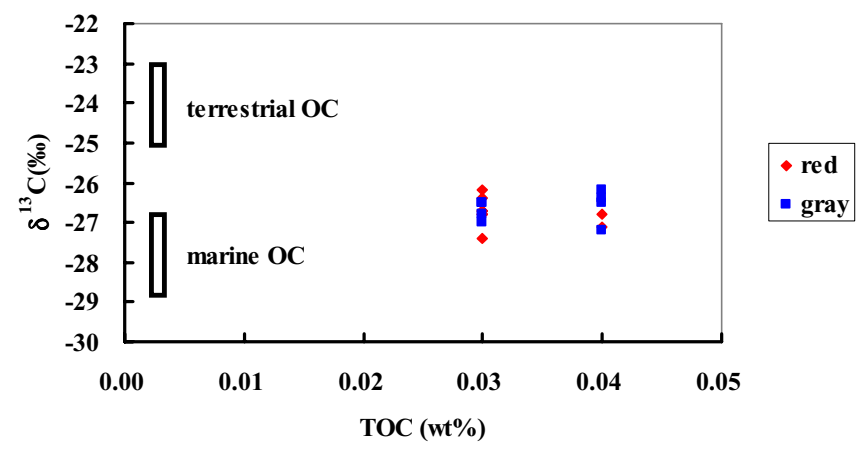

Figure 11. TOC contents and $\delta^{13} \mathrm{C}$ values of the shales.

are $\sim 2$ to $3 \%$ o lighter. Dean and Arthur (1987) suggested that at Site 603 , the organic matter is largely terrestrial, probably derived from the coastal wetlands of North America that produced extensive Cretaceous coal deposits (Parrish et al., 1982). In contrast, at Site 367, the organic matter is largely marine, derived from accumulations of phytoplankton debris in highly productive shelf and slope environments under strong upwelling conditions that existed along the coast of Northwest Africa in the Cretaceous (Barron, 1985). It is suggested that the organic matter in the marine sediments at Sites 603 and 367 represents two different end-member sources for organic matter in Cretaceous proto-Atlantic Ocean (Dean and Arthur, 1987). Our data $\left(\delta^{13} \mathrm{C}=-26.2\right.$ to $-27.4 \%$ ) suggest that the $\mathrm{OC}$ in the red and gray shales from the Mazak Formation may have been derived from a mixing of terrestrial and marine organic matters in a fairly constant proportion, suggested by the small variation in $\delta^{13} \mathrm{C}$ (Figure 11). The isotope data also indicate that the organic matter was mainly marine, mixed with some terrestrial organic matter and deposited in well-oxygenated bottom waters.

The intercalated red and gray shales in the Mazak Formation of Cenomanian age from the Czech Republic were deposited below $\mathrm{CCD}$ in one of the tectonic troughs developed along northern margin of the western Tethys. Our analyses show similar geochemical covariance of major, trace and rare earth elements for both gray and red shales, suggesting similar palaeoceangraphic conditions and provenance. Association and variation of major elements ( $\mathrm{Si}, \mathrm{Ti}$, $\mathrm{Al}, \mathrm{Fe}, \mathrm{Mn}, \mathrm{Ca}, \mathrm{K}, \mathrm{Na}$, and P), trace elements (Zr, Hf, Sc, Th, Mo, V, $\mathrm{Ni}, \mathrm{U}$ ), and rare earth elements support the interpretation that both the red and gray shales were deposited in an oxygenated, pelagic deep-sea environment, possibly similar to the environments presently accumulating pelagic red clays in the deep basins of the Pacific and Atlantic oceans (Jansa et al., 1979).

We consider it important that our geochemical study of these multicolored shales indicate that the most probable cause for the variation of redox bottom conditions in the mid-Cretaceous deep ocean were periodic changes in the concentration of dissolved oxygen in bottom waters. We can only speculate what such changes could be. They can emanate from changes in the source of the bottom water, or as result of major changes in bottom ocean water circulation, due to changes in basins orography, as the mid-Cretaceous was a period of intensified, global, plate tectonic changes.

The variegated shales of the Mazak Formation are sandwiched between Albian black shales of Scisti e Fucoidi facies below and similar dark gray shales of Turonian age above. The variegated beds do not occur in other parts of the Lower and mid-Cretaceous, thus they do represent, on a broader time scale, a unique paleoceanographic event. They represent an amalgamation of two different processes. One, which resulted in general increase in oxygenation of bottom waters, and the second one, which drives the cyclic red/green bed alteration. The cause of the first process, as mentioned above, could have been a temporary inflow of more oxygenated bottom waters. However, the alternative hypothesis which should not be discarded is that the sediments oxidation is result of a major decrease in sedimentation rates (Buckley and Cranston, 1988 and references herein). However, as the sediments were deposited below $\mathrm{CCD}$, they lack any calcareous microfossils to allow high biostratigraphic resolution of the age for the strata, to compute sedimentation rates.

The red/green bed cyclicity is of similar scale to that observed on Mesozoic and Cenozoic sediments in the western Tethys, interpreted as resulting from climate changes triggered by the precession of the earth rotation axis (circa 21ka period, Dean et al., 1978; Herbert et al., 1986).

\section{Conclusions}

Our geochemical study indicates that the shales from the Mazak Formation in Czech Republic show the following major characteristics:

1) The major element chemistry of the red and gray shales shows similar range of variations, with contents of $\mathrm{SiO}_{2}$ of $64.7-$ $69.9 \mathrm{wt} \%, \mathrm{Al}_{2} \mathrm{O}_{3}$ of $13.9-17.6 \mathrm{wt} \%, \mathrm{MgO}$ of $1.86-2.08 \mathrm{wt} \%$, $\mathrm{K}_{2} \mathrm{O}$ of $2.80-3.49 \mathrm{wt} \%$, and $\mathrm{Na}_{2} \mathrm{O}$ of $0.51-0.86 \mathrm{wt} \%$. The red shale shows a significantly higher $\mathrm{Fe}_{2} \mathrm{O}_{3}$ contents (2.84$4.16 \mathrm{wt} \%)$ than those of the gray shales (1.86-2.64 wt\%) and contains some amounts of hematite.

2) The trace element concentrations of the red and gray shales are comparable with each other, and they are broadly similar to those of average upper continental crust, although a depletion in $\mathrm{Sr}$, $\mathrm{Zr}, \mathrm{Mo}, \mathrm{Ba}, \mathrm{Hf}$, and $\mathrm{U}$, and enrichment in $\mathrm{Li}, \mathrm{Cu}, \mathrm{Rb}$ and $\mathrm{Cs}$ are observed in both the red and gray shales. The shales contain low concentrations of the redox-sensitive elements such as Mo, V, $\mathrm{Ni}$, and $\mathrm{U}$.

3) The red and gray shales display similar flat PAAS-normalized REE patterns with slightly heavy rare earth element (HREE) depletions $\left(\mathrm{La}_{\mathrm{N}} / \mathrm{Yb}_{\mathrm{N}}=0.83-1.34\right.$ and $1.0-1.30$, and $\mathrm{Gd}_{\mathrm{N}} / \mathrm{Yb}_{\mathrm{N}}$ ratios $=1.18-1.36$ and $1.05-1.43$, respectively), significant positive $\mathrm{Ce}$ anomalies $\left(\mathrm{Ce} / \mathrm{Ce}^{*}=1.04\right.$ to 2.06 in the red shale, and 1.01-1.34 in the gray shale ), and negative $\mathrm{Eu}$ anomalies $\left(\mathrm{Eu} / \mathrm{Eu}^{*}=0.51-0.69\right.$ and $\left.0.57-0.71\right)$.

4) The red and gray shales show extremely low TOC contents of $<0.04 \mathrm{wt} \%$ and a limited range of $\delta^{13} \mathrm{C}$ TOC values from -26.2 to $-27.4 \%$. In conclusion, the variegated shales of the Mazak Formation (mid to late Cenomanian) deposited below CCD, in a well-oxygenated bottom waters. Organic matter supply was limited and dominated by organic matter of marine origin, which was mixed with some terrestrial organic matter. Both of these shales were deposited in a similar palaeoceanographic setting and are of similar provenance.

Lack of changes in bioproductivity-sensitive elements suggest, that the occurrence of deep sea oxic deposits is most probably result of periodic increase in dissolved oxygen in bottom waters. We suggest that the inflow of colder bottom waters was triggered by local tectonics, resulting from intrabasinal morphological changes effecting ocean floor. 


\section{Acknowledgements}

Financial support for this research was provided by a State Key project of China (grant no. 2006CB701402-03) and Czech Grant Agency (grant no. 205/05/0917). We thank D. Matysek from Technical University in Ostrava for information about mineralogy composition in studied profile. Dr. Kosei E Yamaguchi and an anonymous reviewer provided very useful comments which imporved this manuscript significantly. It is a contribution to the IGCP 463.

\section{References}

Arthur, M.A., 1979, Origin of Upper Cretaceous multicolored claystones of the western Atlantic. Initial Reports of the Deep Sea Drilling Project 43, 417-420.

Bau, M., Koschinsky, A., Dulski, P., and Hein, J., 1996, Comparison of the partitioning behaviours of yttrium, rare earth elements, and titanium between hydrogenetic marine ferromanganese crusts and seawater. Geochimica et Cosmochimica Acta 60(10), 1709-1725.

Barron, E.J., 1985, Numerical climate modeling, a frontier in petroleum source rock prediction: Results based on Cretaceous simulations. American Association of Petroleum Geology Bulletin 69, 448-459.

Buckley, D.E., and Cranston, R.E., 1988., Early diagenesis in deep sea turbidites: The imprint of paleo-oxidation zones. Geochimica et Cosmochimica Acta, vol. 52, 2925-2939.

Brumsack, H.-J., 1986, The inorganic geochemistry of Cretaceous black shales (DSDP Leg 41) in comparison to modern upwelling sediments from the Gulf of California and the Black Sea. Geologische Rundschau 78, 851882.

Dean, W. E. Gardner, J.V., Jansa, L. F., Cepek, P., and Seibold, E., 1978, Cyclic sedimentation along the continental margin of Northwest Africa, in: Lancelot, Seibold et al., Initial Reports of DSDP 41, Washington, 965-989.

Dean, W.E., Arthur, M.A., 1987, Inorganic and organic geochemistry of Eocene to Cretaceous strata recovered from the Lower Continental Rise, North American basin, Site 603, Deep Sea Drilling Project Leg 93. Initial Reports of the Deep Sea Drilling Project 93, 1093-1137.

Dean, W.E., Arthur, M.A., and Stow, D.A.V., 1984, Origin and geochemistry of Cretaceous deep-sea black shales and multicolored claystones, with emphasis on deep sea drilling project site 530, southern Angola basin. Initial Reports of the Deep Sea Drilling Project 75, 819-830.

Dean, W.E., Gardner, J.V., and Hemphill-Haley, E., 1989, Changes in redox conditions in deep-sea sediments of the subarctic North Pacific ocean: possible evidence for the presence of North Pacific Deep Water. Paleoceanography 4 (6), 639-653.

Elderfield, H., 1988, The oceanic chemistry of the rare-earth elements. Phil. Transaction of the Royal Society, London A325, 105-126.

Herbert, T.D., Stallard, R.F., and Fischer, A.G., 1986, Anoxic events, productivity rhythms, and the orbital signature in a mid-Cretaceous deepsea sequence from central Italy. Paleoceanography, 1, 495-506.

Hu, X.M., Jansa, L., Wang, C.S., Sarti, M., Bak, K., Wagreich, M., Michalik, J., and Sotak, J., 2005a, Upper Cretaceous oceanic red beds (CORBs) in the Tethys: occurrences, lithofacies, age, and environments. Cretaceous Research 26, 3-20.

Hu, X., Jansa, L. and Sarti, M., 2005b, Mid-Cretaceous oceanic red beds in the Umbria-Marche Basin, central Italy: constraints on paleoceanography and paleoclimate. Palaeogeography, Palaeoclimatology, Palaeoecology 233, 163-186.

Jansa, L.F, Enos, P. and Tucholke B.E., 1979, Mesozoic-Cenozoic sedimentary formations of the North American Basin, western North Atlantic. In: M. Talwani, W. Hay and W.B.F. Ryan eds.: Deep Drilling Results in the Atlantic Ocean: Continental margins and Paleo-Environment. American Geophysical Union 3, 1-57.
Jakobsson, M., Lovlie, R., Al-Hanbali, H., Arnold, E., Backman, J. and Moerth, M., 2000, Manganese and color cycles in Arctic Ocean sediments constrain Pleistocene chronology. Geology 28 (1): 23-26.

Lancelot, Y., Hathaway, J.C. and Hollister, C.D., 1972, Lithology of sediments from the Western North Atlantic Leg 11 Deep Sea Drilling Project. Initial Reports of the Deep Sea Drilling Project 11, 901-949.

Li, Y.H. and Schoonmaker, J.E., 2003, Chemical composition and mineralogy of marine sediments, pp. 1-35. In Sediments, Diagenesis, and Sedimentary Rocks (ed. F.T. Mackenzie) Vol. 7 Treatise on Geochemistry (eds. H.D. Holland and K.K. Turekian), Elsevier-Pergamon, Oxford.

Melinte, M.C. and Jipa, D., 2005, Campanian-Maastrichtian marine red beds in Romania: biostratigraphic and genetic significance. Cretaceous Research 26, 49-56.

Moffett, J.W., 1990, Microbially mediated cerium oxidation in seawater. Nature 345, 421-423.

Moffett, J.W., 1994, The relationship between cerium and manganese oxidation in the marine environment. Limnol. Oceanography 39, 13091318.

Neuhuber, S., Wagreich, M., Wendler, I. and Spötl, C. 2007, Turonian Oceanic Red Beds in the Eastern Alps: Concepts for palaeoceanographic changes in the Mediterranean Tethys. Palaeogeography, Palaeoclimatology, Palaeoecology 251, 222-238.

Parrish, J.T., Ziegler, A.M. and Schotese, C.R., 1982, Rainfall patterns and the distribution of coals and evaporates in the Mesozoic and Cenozoic. Palaeogeography, Palaeoclimatology, Palaeoecology 40, 67-101.

Pattan, J.N. and Banakar, V.K., 1993, Rare earth element distribution and behavior in buried manganese nodules from the Central Indian Basin. Marine Geology 112, 303-312.

Picha f.J., Stranik Z., Krejci O. 2006, Geology and hydrocarbon resources of the Outer Western Carpathians and their foreland, Czech Republic. In Golonka J. and Picha F.J. (eds.) The Carpathians and their foreland: Geology and hydrocarbon resources. AAPG Memoir 84, 49-175.

Piepgras, D.J. and Jacobsen, S.B., 1992, The behavior of rare Earth elements in seawater: precise determination of variations in the North Pacific water column. Geochimica et Cosmochimica Acta, 56, 1851-1862.

Piper, D.Z., 1974. Rare Earth elements in the sedimentary cycle: a summary. Chemical Geology 14, 258-304.

Quinby-Hunt, M.S. and Wilde, P., 1994, Thermodynamic zonation in the black shale facies based on iron-manganese-vanadium content. Chemical Geology 113, 297-317.

Quinby-Hunt, M.S. and Wilde, P., 1996, Chemical depositional environments of calcic marine black shales. Economic Geology 91, 4-13.

Robb, G.J., 1949. Red bed coloration. Journal of Sedimentary Petrology 19(3), 99-103.

Rudnick, R.L. and Gao, S., 2003, Composition of the Continental Crust, pp. 1-64. In The Crust (ed. R.L. Roberta) Vol. 3 Treatise on Geochemistry, (eds. H.D. Holland and K.K. Turekian), Elsevier-Pergamon, Oxford.

Taylor, S.R. and McLennan, S.M., 1985. The continental crust: its composition and evolution. Blackwell, Oxford, 1985.

Velde, B., 2003, Green clay minerals, pp.309-324. In Sediments, Diagenesis, and Sedimentary Rocks (ed. F.T. Mackenzie) Vol. 7 Treatise on Geochemistry (eds. H.D. Holland and K.K. Turekian), Elsevier-Pergamon, Oxford.

Vogt, P.R., 1972, Evidence for global synchronism in mantle plume convection, and possible significance for geology. Nature 240, 338342 .

Von Breymann, M.T., Emeis, K.C., and Camerlenghi, A., 1990, Geochemistry of sediments from the Peru upwelling area: Results from ODP Sites 680, 682, and 688. Proceedings of Ocean Drilling Project, Scientific Results $112,491-503$.

Von Breymann, M.T., Emeis, K.C., and Suess, E., 1992, Water-depth and diagenetic constraints in the use of barium as a paleoproductivity indicator. In: Summerhayes, C.P., Prell, W., Emeis, K.C. (eds.), Evolution of Upwelling Systems since the Early Miocene. Geological Society of London, Special Publications 64, 273-284. 
Wang, C.S., Hu, X.M., Sarti, M., Scott, R.W., and Li, X.H, 2005, Upper Cretaceous oceanic red beds in southern Tibet: a major change from anoxic to oxic, deep-sea environments. Cretaceous Research 26, 21-32.

Wortmann, U.G., Hesse, B., and Zacher, W., 1999, Major-element analysis of cyclic black shales: Paleoceanographic implications for the Early Cretaceous deep western Tethys. Paleoceanography 14(4), 525-541.

Yamaguchi, K.E. and Ohmoto, H., 2006, Geochemical and isotopic constraints on the origin of Paleoproterozoic red shales of the Gamagara/Mapedi Formation, Postmasburg Group, South Africa. South African Journal of Geology 109, 123-138.

Yang, J-H., Jiang, S-Y., Ling, H-F., Feng, H-Z., Chen, Y-Q,. and Chen, J-H., 2004, Paleoceangraphic significance of redox-sensitive metals of black shales in the basal Lower Cambrian Niutitang Formation in Guizhou Province, South China. Progress in Natural Sciences 14(2), 152-157.

Zhou, L. and Kyte, F.T., 1992, Sedimentation history of the South Pacific pelagic clay province over the last 85 Million years inferred from the geochemistry of deep sea drilling project hole 596. Paleoceanography 7(4), 441-465.

Shao-Yong Jiang received his PhD degree from Bristol University in England in 1995; from 1996-1999 he was a Postdoctoral Researcher and Humboldt Research Fellow at Max Planck Institute for Chemistry in Mainz, Germany. From 1999 till the present he works at the State Key Laboratory for Mineral Deposits Research, Department of Earth Sciences, Nanjing University, China, where he is presently a Professor and Director. His interests cover geochronology and isotope geochemistry, hydrothermal mineralization, marine geochemistry and palaeoceanography.
Petr Skupien is an Associate Professor of geology at the VSB Technical University in Ostrava, Czech Republic. He received his M.S. (1995) and Ph.D. (1999) degrees in geology from the Faculty of Mining and Geology of the VSBTU in Ostrava. From 1995 he is lecturer and research geologist in the Institute of Geological Engineering. His research interests focus on biostratigraphy, palaeo-geography, palaeoecology, litho-stratigraphy and basic geological research, especially of the Alpine-Carpathian area.

Luba Jansa received his PhD degree from Charles University in Prague; from 1969-1970 he was visiting scientist at University of Illinois, USA. From 1971 till the present he works at the Geological Survey of Canada, where he is presently an Emeritus Scientist. His interests are confluence of climate, tectonics and environments on sedimentary rocks. His studies included Mesozoic of North Atlantic continental margins in relation to hydrocarbon occurrences, Mesozoic in Europe, western Africa and Tibet, and presently Sinian and Paleozoic in southern China.
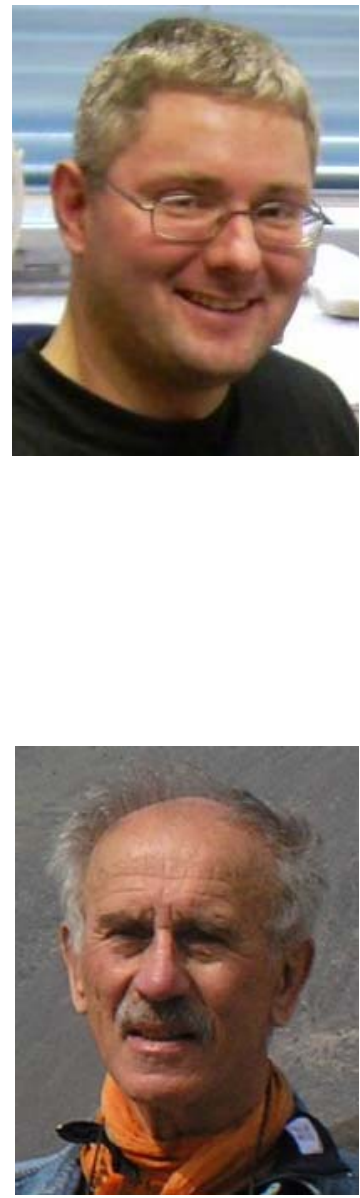